\title{
Energy efficiency in South Africa: policy perspectives and the path to low carbon growth
}

\author{
G. Nhamo \& A. Bimha \\ University of South Africa, South Africa
}

\begin{abstract}
Energy efficiency is becoming one of the key paths to transforming the South African economy into low carbon growth. This vision has been accepted by both the government and business community. To this end, the White Paper on Energy, National Energy Efficiency Strategy of 2005 (revised 2008), Energy Efficiency Accord and the National Climate Change Response Green Paper are among key policy documents. The Energy Efficiency Strategy spelt out a target of a national final energy demand reduction of $12 \%$ by 2015 . Industry and Government agreed that the Energy Efficiency Strategy should be reviewed in three-year cycles. This paper reviews and assesses the energy efficiency policy landscape in South Africa and how this is assisting the nation to transform into a globally recognised low carbon economy. We conclude that South Africa is progressing well in terms of putting in place new as well as refining old pieces of legislation on energy efficiency leading to a low carbon growth path.
\end{abstract}

Keywords: energy efficiency, South Africa, low carbon growth, climate change.

\section{Introduction}

The International Chamber of Commerce (ICC) realizes that energy efficiency is a critical component if the world is to move sustainably to a low carbon, sustainable energy economy ICC [1]. According to the ICC, a number of benefits are associated with energy efficiency and these include: reduced production, distribution and marketing associated costs; reduced emissions and other environmental impacts; extended availability of large but non-renewable resources; improved competitiveness and overall productivity; and making energy more affordable to consumers, especially in developing countries. 
Energy efficiency is very high on both the South African government and private sector policy agendas (Figure 1). The national government takes the lead in energy efficiency and is currently using its buildings as an example. Among key government policies and industry initiatives reviewed making reference to energy efficiency were: the National Climate Response Green Paper (NCCGP), Draft Carbon Tax Option (DCTO), Industrial Policy Action Plan II (IPAP II), Draft Integrated Resources Plan (DIRP), South African Renewables Initiative (SARI), Western Cape Government Green Procurement Policy (WCGGPP), National Energy Act (NEA), Long Term Mitigation Scenario (LTMS), revised National Energy Efficiency Strategy (NEES), Energy Efficiency Accord (EEA), White Paper on Energy Policy (WPEP), White Paper on Renewable energy (WPRE) and the Carbon Disclosure Project South Africa (CDP SA). From Figure 1, the revised National Energy Efficiency Strategy (NEES) of 2009 stands out as the key policy document in terms of energy efficiency.

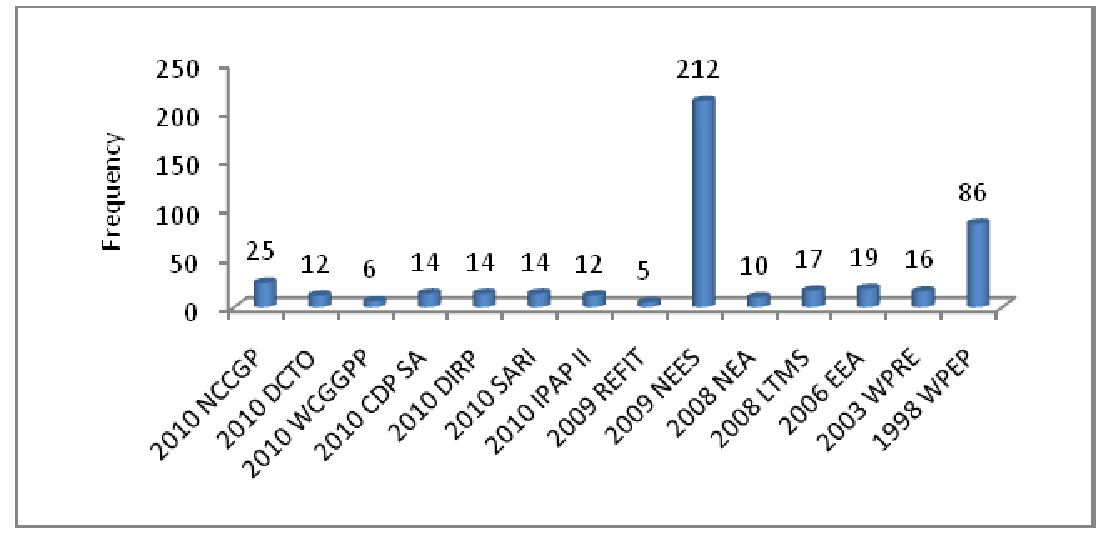

Figure 1: $\quad$ Energy efficiency mentioned in key South African policies.

\section{Energy efficiency: an international perspective}

In order to promote energy efficiency within communities, the ICC [1] identifies a number of policy directions. These include: advanced technology development, combined heat/cooling and power production, technology transfer and cooperation, fiscal instruments, energy services, building codes and standards, voluntary commitments and partnerships and consumer information. The World Economic Forum (WEF) maintains that energy efficiency should be the cornerstone to meeting the climate change goals WEF [2]. Energy efficiency will also enable humanity to meet the growing energy demand. If per capita energy demand continues unabated, then "energy demand is expected to increase by $40 \%$ by 2050 , carbon emissions to increase to $34.5 \mathrm{GT} \mathrm{CO}_{2}$ by 2020 and $40.2 \mathrm{GT} \mathrm{CO}_{2}$ by 2030 " and capital required to meet projected energy demand to 2030 will cumulatively be US\$ 26 trillion (in 2008 dollars). Various policies and schemes have been put in place addressing energy efficiency. For example, the 
EU aims to reduce energy use by $20 \%$ through cost-effective demand and supply measures ICC [1]. The G8 identified energy efficiency as a major element requiring action leading to reduced emissions whilst improving competitiveness, health and employment. As of 2005, 37 countries had ratified energy-efficiency labeling systems for appliances and electronic equipment (UNEP et al. [3]. UNEP et al. [3]) highlights how energy efficiency has a huge potential for creating jobs. Energy efficiency has been recognized as part of the growing green global markets. UNEP et al. [3] noted that the global market volume for environmentally sound technologies (products and services) was estimated at about $\$ 1,370$ billion ( $€ 1,000$ billion) in 2008 with a projected $\$ 2,740$ billion $(€ 2,200$ billion) by 2020 . Energy efficiency technologies that included appliances, industrial processes, electrical motors, insulation, etc had a share of $\$ 617$ billion ( $€ 450$ billion) in 2008 and this was estimated to rise to $\$ 1,233$ billion (€900 billion) by 2020 .

Energy efficiency has been taken seriously in China. In fact, China has been ranked the world's number one in terms of the Ernst and Young 'All Renewables Index' for November 2010 (Ernst and Young [4]). The Chinese government demands that the efficiency of pumps and fans be improved from a typical 75-80 percent in 2000 to $80-87$ percent, and coal fired industrial boilers from 65 percent to $70-80$ percent (both by 2010). It has also mandated a reduction, between 2000 and 2020, of energy needed per ton of steel produced from 906 $\mathrm{kgs}$ of coal equivalent (kgce) to 700; for aluminum from 9.9 tons of coal equivalent to 9.2 tons; and for cement from $181 \mathrm{kgce}$ to $129 \mathrm{kgce}$. These measures are ambitious, but also very difficult to implement (Martinot and Junfeng [5]). In the UK there is a requirement to comply with stringent energyefficiency agreements National Treasury [6]. The agreements are negotiated with sector associations and the results of the agreements are reviewed regularly with continued discounts relying on targets being achieved.

A Carbon Disclosure Project (CDP) 2010 report on Corporate Clean Energy Investment Trends in Brazil, China, India and South Africa (BASIC) looked at energy efficiency. In Brazil the strong regulatory requirements for the energy sector are having an effect on corporate investment and companies still wish to see good performance in energy efficiency recognised through a corporate energy efficiency index or individual energy efficiency contracts with government CDP [7]. In China high-level policy signals have been effective in stimulating investment in energy efficiency. Although there is still an appetite for more specific regulation applicable to a larger number of companies, green finance measures have been effective in promoting energy efficiency investments. Like in Brazil companies would like to see measures that provide incentives or recognition for good energy efficiency performance CDP [7].

\section{South Africa's policy on energy efficiency}

A number of energy efficiency policies and regulatory regimes are already in place in South Africa. These have been designed to address, especially the negative impacts of climate change. In addition, energy efficiency is seen as a 
tool for managing demand in a country that was plugged with blackouts in 2008 . Among the noticeable policies and legislative initiatives addressing energy efficiency is the: White Paper on Energy, National Energy Act, revised National Energy Efficiency Strategy, Energy Efficiency Strategy, Industrial Policy Action Plan II, Integrated Resources Plan, National Climate Change Green Paper, Carbon Tax Option, Taxation Laws Amendment Act and the National Greenhouse Gas (GHG) emissions pledge of 2009. These and other initiatives will now be considered in the next sections.

\subsection{Energy White Paper for South Africa - 1998}

The White Paper DME [8] identified the use of standards and appliance labelling as the entry level interventions when implementing energy efficiency. At the time of finalising the White Paper, there were no energy efficiency standards, norms or regulations. Government had to promote energy efficiency awareness in households. It was estimated that energy efficiency could save between $10 \%$ and $20 \%$ of consumption at that time. Energy efficiency norms and standards for commercial buildings and industrial equipment as well as voluntary guidelines for the thermal performance of housing were to be established in the near future. Energy efficiency and conservation were twin pillars to an overall energy policy. Energy efficiency had to be an integral element to the Integrated Resource Planning (IRP) framework. The IRP considers both the supply and demand side options for meeting energy service requirements. The White Paper also established that South African energy consumers in industry and commerce were generally unaware of a need for and the potential of energy efficiency improvements and savings. The lack of energy efficiency expertise in industry was also identified as one of the major barriers. Government pledged to investigate possibilities of establishing appropriate institutions and build capacity for implementing energy efficiency strategies. Appropriateness of using environmental levies on energy sales would be investigated.

\subsection{National Energy Act -2008}

The Act establishes the South African National Energy Development Institute whose functions in respect of energy efficiency include the need to: (i) undertake energy efficiency measures as directed by the Minister; (ii) increase energy efficiency throughout the economy; (iii) increase the gross domestic product per unit of energy consumed; and (iv) optimise the utilisation of finite energy resources RSA [9]. The Act also gives the responsible Minister power to promulgate energy efficiency standards for specific technologies, processes, appliances, devices, motor vehicles and buildings.

\subsection{National Energy Efficiency Strategy - 2005 (revised 2008)}

The initial Energy Efficiency Strategy was finalised in 2005 DME [10]. The Strategy spelt out a target of a national final energy demand reduction of $12 \%$ by 2015 and this has remained the same in the revised Strategy DME [11]. This is 
expressed as a percentage reduction against the projected national energy use in 2015. The revised Strategy of 2008 points out to a number of key sectors requiring energy efficiency. The industrial (taking up $36.2 \%$ of consumption in $2004)$, residential $(17.9 \%)$ and mining (7\%) sectors are considered the heavy users of energy DME [11]. The transport sector (taking up 25.7\% of total national energy consumption in 2004) uses up to three-quarters of the country's petroleum products. The "promotion of energy efficient vehicles and those with lower emissions, building a public transport infrastructure and a travel demand management system are some of the key features of the approach adopted" DME [10]. The government makes mention of an electrical appliance labelling initiative launched to rate energy consumption of all new 'white products'. The changing of South African residents' behaviour and raise awareness about the costs and benefits of energy efficiency is deemed the most difficult area although this has been ongoing since 2005. The vision of the Strategy is to "contribute towards affordable energy for all, and to minimise the negative effects of energy usage upon human health and the environment and contributing towards secure and affordable energy for all" DME [11]. The vision will be achieved by encouraging sustainable energy development and energy use through efficient practices in the country. The Strategy will be implemented through Sectoral Implementation Plans with systems put in place to permit periodical monitoring of progress against the spelt out target to be reviewed at the end of each phase. The eight goals of the strategy are organised under the three pillars of sustainable development namely: social, environmental and economic sustainability.

The Strategy makes provision for sector programmes in the following sectors: Industry and Mining, Commercial and Public Buildings, Residential and Transport. Cross-cutting issues are also identified including: Integrated Energy Planning, Renewable Energy, Environment and Health as well as The Cleaner Fuels Programme. The strategy also dedicates a section dealing with climate change and how the DoE has established the National Designated authority to deal with CDM projects. Six barriers to energy efficiency are identified in the Strategy to include: Energy Pricing, Lack of knowledge and understanding of Energy Efficiency, Institutional barriers and resistance to change, Lack of investment confidence and practice of 'bounded rationality' DME [11]. The DME [11] notes that a few countries have set comprehensive targets for energy efficiency and these countries include Slovenia, Japan, The Netherlands and New Zealand. The South African Strategy provides for the implementation of sector programmes in a three-phase approach, timed as follows: Phase 1 - March 2005 to February 2008 (completed); Phase 2 - March 2008 to February 2011; and Phase 3 - March 2011 to February 2015. A review of the national and sectoral targets will continue to be done after the end of each phase. As the industrial and mining sectors in the country are different, it was agreed that sub-sectoral targets should be implemented. Further details regarding the targets are spelt out in Table 1.

The Energy Act will be used to implement regulations on the management, measurement, monitoring and reporting of energy efficiency DME [11]. The 
DoE is to establish a formal system that will facilitate continuous updating of registered "figures related to energy efficiency; in particular, indicators for efficiency measurement" DME [11]. Such a system will involve a multistakeholder engagement process. A number of supporting mechanisms and instruments will be used and these include: Efficiency Standards; Appliance Labelling; Certification and Accreditation; Education, Information and Awareness; Research and Technology; Regulation; Energy Audits and Energy Management Systems. With regards to finance instruments the following will be applied: Incentives, Fee Bates, Financing the Public Sector Implementation Plan, Energy Service Companies, CDM, Voluntary and retail carbon markets, Demand Side Management and Energy Pricing. Lastly, the Strategy identifies cross-cutting and closely linked issues that include integrated energy planning, renewable energy, environment and health and Cleaner Fuels Programme.

Table 1: $\quad$ Energy efficiency targets.

\begin{tabular}{|l|l|}
\hline \multicolumn{1}{|c|}{ Sector (S)/Sub-sector (SS) } & \multicolumn{1}{c|}{ Target to 2015 } \\
\hline Industry and Mining Sector (S) & Final Energy Demand Reduction of $15 \%$ \\
\hline Iron and Steel Industry (SS) & Improvement in energy intensity of 1\% per annum \\
\hline $\begin{array}{l}\text { Chemical and petrochemical industries } \\
\text { (SS) }\end{array}$ & Improvement in energy intensity of 1\% per annum \\
\hline Mining (SS) & $\begin{array}{l}\text { Final energy demand reduction of 10\% by 2015 } \\
\text { (using an adjustable baseline) }\end{array}$ \\
\hline $\begin{array}{l}\text { Paper and pulp and printing industries } \\
\text { (SS) }\end{array}$ & Improvement in energy intensity of 2\% per annum \\
\hline Cement industry (SS) & Improvement in energy intensity of 2\% per annum \\
\hline Power Generation (S) & $\begin{array}{l}\text { Target of 15\% reduction in "parasitic" electrical } \\
\text { usage }\end{array}$ \\
\hline Commercial and Public Building (S) & Target Final Energy Demand Reduction of 20\% \\
\hline Residential (S) & Target Final Energy Demand Reduction of $10 \%$ \\
\hline Transport (S) & Target Final Energy Demand Reduction of $9 \%$ \\
\hline
\end{tabular}

Source: Authors, based on DME [11].

\subsection{Energy Efficiency Accord - 2005}

The Energy Efficiency Accord (Accord) was adopted for implementation in 2005 following the conclusion of the Energy Efficiency Strategy of the Republic of South Africa in 2005 DME [10]. In the Accord, industry and government committed to a number of outputs and outcomes as outlined in Table 2. Industry and Government agreed that the Energy Efficiency Strategy should be reviewed regularly in three-year cycles. The review would take the form of a collaborative process between the Parties. Furthermore, the Energy Efficiency accord compels signatory industries to develop a specific energy efficiency strategy within one year of the signing of the Accord. The National Business Initiative (NBI) would act as the liaison with Government whilst Business Unity South Africa was mandated to deal with legislative issues. 
Table 2: Commitments by industry and government.

\begin{tabular}{|c|c|}
\hline Industry's commitment & Government's commitment \\
\hline $\begin{array}{l}\text { Promote the development of sector specific } \\
\text { strategies and targets; } \\
\text { Promote the use of Demand Side Management } \\
\text { contracts concluded with energy suppliers, where } \\
\text { they exist, and to negotiate additional such } \\
\text { contracts where appropriate, towards achievement } \\
\text { of the above target; } \\
\text { develop common reporting requirements for } \\
\text { energy usage from all energy sources, taking into } \\
\text { account, where possible, existing internationally } \\
\text { recognised protocols for reporting such as those } \\
\text { developed by the Global Reporting Initiative; } \\
\text { define industry-specific projected energy use in the } \\
\text { future, based on Business-unusual (BAU) growth } \\
\text { expectations; } \\
\text { agree on } 2000 \text { as the baseline year against which } \\
\text { performance will be measured; } \\
\text { establish methodologies that will allow the } \\
\text { baseline quantification for energy use/intensity in } \\
\text { various sub sectors, and to take into account the } \\
\text { need to measure specific energy intensity } \\
\text { (providing for the differing sub sectors) rather than } \\
\text { absolute energy use in order to promote industrial } \\
\text { growth whilst achieving energy efficiency and } \\
\text { recognising the energy conservation measures } \\
\text { already in use in some sub sectors; } \\
\text { establish methodologies to take into account } \\
\text { increased production so that the pursuit of } \\
\text { improved energy efficiency does not hamper } \\
\text { industrial growth; } \\
\text { develop a generic energy auditing protocol that can } \\
\text { be adapted for use by the individual sector and } \\
\text { company signatories; } \\
\text { endeavour that, where appropriate, training } \\
\text { material prepared during the course of this accord } \\
\text { be accredited through the relevant SETA and that } \\
\text { the sector skills plans of the various sectors include } \\
\text { the development of the skills necessary to sustain } \\
\text { the commitments made in this accord; and } \\
\text { Where appropriate, exploit opportunities presented } \\
\text { by energy efficiency projects to develop CDM } \\
\text { projects. }\end{array}$ & $\begin{array}{l}\text { - } \\
\text { signage with industries leading up to the } \\
\text { three yearly interval reviews } \\
\text { that are envisaged in the } \\
\text { Strategy; } \\
\text { develop strategies, including } \\
\text { the provision of fiscal and other } \\
\text { incentives with signatories to } \\
\text { incentivise the achievement of } \\
\text { agreed sectoral targets by } \\
\text { industry on a sector or } \\
\text { enterprise basis; } \\
\text { afford signatories the } \\
\text { opportunity to provide input to } \\
\text { the concept and structure of } \\
\text { future energy related strategy, } \\
\text { regulations and standards; } \\
\text { build a relationship of trust and } \\
\text { cooperation with signatories; } \\
\text { encourage and enable } \\
\text { information sharing and } \\
\text { networking activities with the } \\
\text { private sector and to seek } \\
\text { synergy with the greenhouse } \\
\text { gas initiatives undertaken by } \\
\text { the Department of } \\
\text { Environmental Affairs and } \\
\text { Tourism; } \\
\text { identify and share Best } \\
\text { Practices (where appropriate to } \\
\text { the South African context) } \\
\text { among all parties and consider } \\
\text { them as the basis for the } \\
\text { establishment of standards; } \\
\text { recognise industry signatories } \\
\text { as contributors to the ongoing } \\
\text { process to revise the National } \\
\text { Energy Efficiency Strategy; and } \\
\text { Promote CDM projects as a } \\
\text { vehicle to achieve improved } \\
\text { energy efficiency. } \\
\text { - }\end{array}$ \\
\hline
\end{tabular}

Source: Authors, based on DME [12].

\subsection{Industrial Action Plan II - 2010}

The Industrial Policy Action Plans (IPAPs) are developed following the adoption of the National Industrial Policy Framework (NIPF) by cabinet in January 2007 DTI [13]. The NIPF sets out the government's broad approach to industrialisation and has as one of the founding objectives the need to strengthen 
"building energy-efficiency standards in response to the national electricity shortage" [13]. As part of the actions in the IPAP II of 2010/11 through to 2012/13, the Department of Trade and Industry (DTI) is set to develop and strengthen national standards to support the creation or resuscitation of specific industries. The South African Bureau of Standards (SABS) will develop national standards as major milestones for the measurement and verification of energy efficiency and energy efficient electric appliances. Other national standards will be developed for solar water heaters, wind energy turbines, automotive diesel fuel and bio-diesel metal free unleaded petrol, alternative fuel vehicles, cogeneration and transport of dangerous goods and globally harmonised system for classification of chemicals.

The IPAP II DTI [13] looks critically at Industrial Energy Efficiency (IEE). This has been linked to the rising electricity prices and increasing commitments in relation to carbon emission reduction. The IEE is viewed as presenting an opportunity for the establishment of an industry in relation to machinery and services which improve energy efficiency in the industrial sector. A potential area for significant increases in energy efficiency is the adjustment and/or replacement of industrial motors. To follow up on the proposed actions, an industrial energy efficiency programme will be developed. The programme will include consideration of more attractive financing models and the scaling up of the capacity of the National Cleaner Production Centre (NCPC). The IEE programme will try to counteract higher energy prices, lower emissions and create new goods and services. The IEE Programme is targeted for full implementation during Q2-Q4 of the 2010/11 cycle with the DTI taking the lead supported by the NCPC, Department of Energy, Department of Environmental Affairs and the Industrial Development Corporation.

\subsection{National Climate change Response Green Paper - 2010}

The Green Paper dedicates a section on energy focusing on the impact that energy efficiency, renewable energy technologies and a nuclear rollout could have on the country's carbon footprint DEA [14]. The industrial sector is identified as having great opportunities for improving energy efficiency that could be realised through improved lighting efficiency, compressed air efficiency, motor efficiency, thermal efficiency, steam system efficiency and HVAC efficiency. The Green Paper makes reference to a need to ensure that the Integrated Resource Plan for Electricity Generation (IRP) DME [15] and its future iterations take account of the peak, plateau and decline trajectory described in the LTMS DEAT [16]. The application of market-based policy measures like carbon tax is highlighted. The use of such market-based policy measures could motivate industry in implementing energy efficiency measures and investments in the development of clean technologies. It is anticipated that in future government will set "ambitious and mandatory targets for energy efficiency" DEA [14]. In addition, ongoing energy efficiency should be scaledup. A call is made to improve energy efficiency knowledge and understanding in the various sectors through awareness campaigns, demonstration programmes, audits and education. The government also plans to work with the mining 
industry to increase energy efficiency in production processes. The hospitality industry is another sector mentioned. The government also wishes to support the development and implementation of energy efficiency plans by municipalities. With regards to the utilisation of waste for energy efficiency, gypsum is singled out as an example of a waste stream that could be reused in the manufacture of ceilings for low income homes leading to increased energy efficiency DEA [14].

\subsection{Reducing GHG Emission: The Carbon Tax Option - 2010}

The discussion document advocates for the pricing of environmental goods and services that generate huge quantities of GHGs Martinot and Junfeng [5]. The pricing must be adjusted to reflect the full costs of production and consumption and carbon taxes are part of a mechanism that can achieve this by encouraging greater energy efficiency and the use of cleaner, low carbon technologies. Tax incentives and specifically targeted government programmes for energy efficiency measures now form part of the government's policy response to climate change. Since 2008, government has implemented a range of taxes and incentives to assist it in managing emission reductions. Among such taxes and incentives are the electricity levy, income tax exemption for revenues generated from the sale of certified emissions reduction units from the CDM projects, taxation of incandescent light bulbs, the $\mathrm{CO}_{2}$ vehicle carbon emissions tax and the proposed energy efficiency savings tax incentive. The discussion document also notes effort being undertaken by the Department of Energy to encourage energy-efficiency measures.

\subsection{Integrated Resources Plan - 2010-203}

The Integrated Resources Plan (IRP) includes a number of critical assumptions, among them, a need for continued investment in demand side management (DSM) initiatives to improve energy efficiency DME [15]. The IRP notes that a decline in energy intensity provides an indication of the expected improvement in energy efficiency. A scenario is presented that assumes the economy growing as per the expected economic growth without any change in energy intensity, then the expected demand will "be significantly higher (at 770 TWh by 2034)" DME [15]. Energy efficiency could bring expected demand down to 496TWh, thus, a saving of $35 \%$. As a separate concept to DSM, energy efficiency focuses on the use of electricity by consumers and the effect of the price increases would impact on energy efficiency.

\subsection{Energy efficiency in other policies}

The Long Term Mitigation Scenario DEAT [16] makes reference to energy efficiency as portrayed in the National energy Efficiency Strategy of 2005 that aims to achieve a final energy demand reduction of $12 \%$ by 2015 [10]. Although not mentioning energy efficiency directly, the South African government pledge towards emissions reduction targets in 2009 has a strong bearing with regards to energy efficiency. President Jacob Zuma announced a pledge to reduce 
emissions by undertaking mitigation actions which will result in a deviation below the current emissions baseline of $34 \%$ by 2020 and $42 \%$ by 2025 . The pledge was conditional on a fair, ambitious and effective global climate change agreement and provision of financial, technology and capacity building support from developed countries The Presidency [17].

\section{Lessons learnt and associated challenges}

The space accorded this paper will not permit a full audit in terms of assessing the implementation of energy efficiency initiatives in South Africa. However, a summary assessment of certain critical elements enshrined in the Energy Efficiency Accord will be done as the Accord remains a key landmark. The growth of signatories of major energy consuming companies from 30 in 2005 to the current 51 (Figure 2) can be considered a success story to the Accord NBI [18]. The Accord's monitoring and verification instrument assisted stakeholders involved in the finalisation of SABS SATS 50010: 2010 dealing with the Measurement and Verification of Energy Savings. This has also resulted in greater recognition of the importance of monitoring and verification of energy savings in the country.

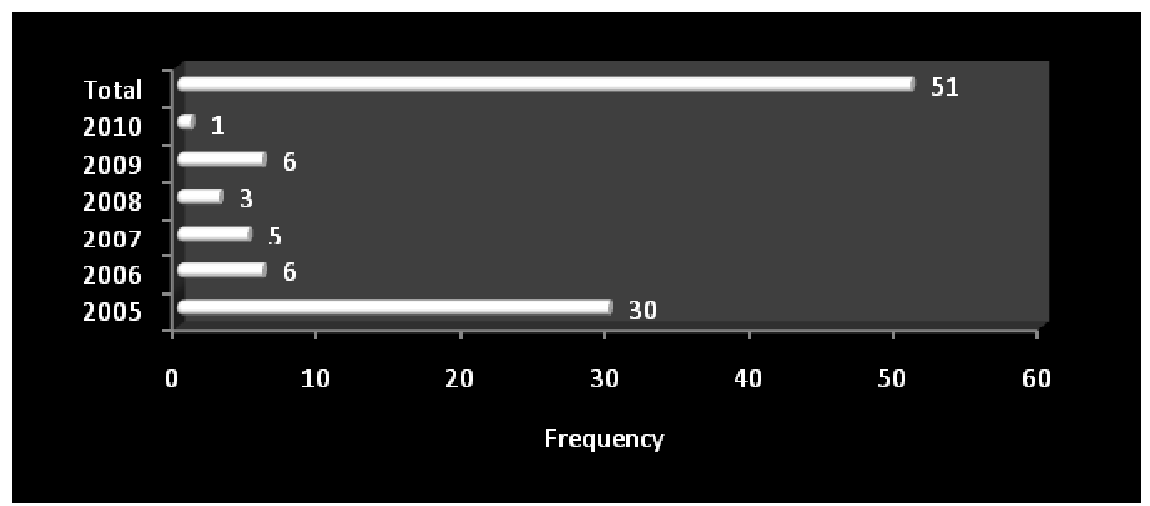

(Source: Authors.)

Figure 2: $\quad$ Trends in Signatories to the EEA (2005-8).

Through the Accord, both business and government agreed to utilise the CDM projects as a vehicle to achieve improved energy efficiency. Judging by the number of CDM project, energy efficiency takes up a significant portion. As of 20 December 2010, out of the 140 CDM projects submitted for consideration to the Designated National Authority, 22 were for energy efficiency, second to 26 for renewable energy DoE [19]. Although energy efficiency contributes significantly to the total number of CDM projects in the country, the overall figure of 140 projects is still low compared to those in competing countries of China (ranked first with $1100 \mathrm{CDM}$ projects recorded during the same time, India with 582 and Brazil with 180 UNFCCC [20]. A 2008 report assessing 
progress with regards to the implementation of the Accord established that the Energy Efficiency Technical Committee (EETC) had been formed with the NBI administering the EETC and acting as the secretariat DME and NBI [21]. The EETC regularly meets to share best practices in terms of energy efficiency as outlined in the Accord. Nineteen out of the 44 signatories to the Accord in 2008 collectively consumed $24 \%$ of the national electricity consumption, a figure in excess of 56,560 GWh DME and NBI [21]. A more recent evaluation from respondents to a questionnaire indicated that the key success of the Accord has been in supporting the enhanced recognition of the importance of energy efficiency in the business sector leading to significant investment in this regard. In terms of key challenges, maintaining the momentum within member companies has been identified. Although a number of companies have been approaching the NBI wishing to sign up to the accord since Q2 of 2010, this has not taken place as the NBI is revising its approach to Energy Efficiency Accord.

\section{Future road map}

The starting point into the future concerns the harmonization of the definition of energy efficiency. The 1998 White Paper on energy defines energy efficiency as "a measure of the savings of energy", which is used to provide goods and services, while maintaining the desired benefits DME [8]. The 2008 National Energy Act defines it as the: "economical and efficient production and utilisation of an energy carrier or resource" RAS [9]. The revised National Energy Efficiency Strategy defines energy efficiency as "achieving the same or improved output with a reduced input of energy" DME [11]. In the draft Integrated Resources Plan DME [11] energy efficiency means "the effective use of energy to produce a given output (in a production environment) or service (from a consumer point of view), i.e. a more energy-efficient technology is one that produces the same service or output with less energy input'. What emerges from the various definitions in government policies is a clear need to harmonise the definitions.

There are also challenges associated with the institutional arrangements and capacity. The various pieces of legislation are administered in no less than 10 different government departments. These include among them the National Energy Regulator, Department of Energy, Department of Trade and Industry, Department of Public Enterprises, South African National Energy Development Institute, Department of Environmental Affairs and National Treasury. This brings bureaucratic delays, competition and inefficiencies. For example, a delay in the implementation of the Electricity Levy or any other Carbon Tax related initiative by the National Treasury holds back the implementation of all other pieces of legislation aimed at energy efficiency that are drafted and passed from other departments. With special reference to the Energy Efficiency Accord there also comes into play industry associations like the NBI and the current 51 member signatories to the Energy Efficiency Accord. The revised National Energy efficiency Strategy DME [11] has come up with a matrix that identifies primary and secondary stakeholders as per the given tasks in energy efficiency. 
The CDM still remains a viable option for implementing energy efficiency in the country. There is need to promote more activity in this space, especially given that there will be a National Climate Change White Paper soon. Member companies to the Accord have clearly indicated that there is value when they work as a collective and share information in the future. Companies are looking forward to a more certain regulatory environment and more analysis of what the regulatory environment means for them. Maintaining momentum moving forward in a context of regulatory uncertainty and institutional changes within government is also a challenge facing the NBI as the key implementing agency. Looking ahead, business has indicated its wish to continue working in the energy efficiency realm with a proposal to develop a Business Network for Leadership in Energy Efficiency. Although questions have been raised in terms of the overlaps between the Energy Efficiency Accord and the CDP, the NBI as implementing agency for both initiatives realises the two initiatives are mutually supportive but different.

\section{Conclusion}

The paper has traversed through a plethora of energy efficiency legal documents in South Africa with most of them being in tandem with international energy efficiency trends. This is an indication that South Africa is progressing well in attaining energy efficiency which is beneficial in transforming to a low carbon economy. There is evidence of government and business' leading and participative roles in formulating and implementing energy efficiency policies. The Energy Efficiency Accord and the CDM have been key initiatives in this regard. Going forward, an integrated approach to energy efficiency institutional arrangements, capacity and legal frameworks is required. The proposal to develop a Business Network for Leadership in Energy Efficiency is a welcome development. More investment will also be required in the CDM space.

\section{Acknowledgement}

The authors wish to thank Exxaro Resources Limited for sponsoring the Chair in Business and Climate Change under Unisa's Institute for Corporate Citizenship.

\section{References}

[1] ICC. Energy Efficiency A world business perspective. Geneva: International Chamber of Commerce; 2007.

[2] WEF. Energy efficiency: Accelerating the agenda. Geneva: Workd Economic Forum; 2010.

[3] UNEP, ILO, IOE, ITUC. Green Jobs: Towards Decent Work in a Sustainable, Low-Carbon World. Nairobi: UNEP/ILO/IOE/ITUC; 2008.

[4] Ernst \& Young. Renewable energy country attractiveness indices. London: Ernest \& Young; 2010. 
[5] Martinot E, Li Junfeng L. Powering China's development: The role of renewable energy. Washington DC: Worldwatch; 2007.

[6] National Treasury. Reducing Greenhouse Gas Emissions: The Carbon Tax Option. Pretoria: National Treasury; 2010.

[7] CDP. Corporate clean energy investment trends in Brazil, China, India and South Africa. London: Carbon Disclosure Project; 2010.

[8] DME. White Paper on the Energy Policy of the Republic of South Africa. Pretoria: Department of Minerals and Energy; 1998.

[9] RSA. National Energy Act (No. 34 of 2008). Cape Town: Government Printers, 2008.

[10] DME. Energy Efficiency Strategy of the Republic of South Africa. Pretoria: Department of Minerals and Energy; 2005.

[11] DME. National Energy Efficiency Strategy of the Republic of South Africa. Pretoria: Department of Minerals and Energy; 2009.

[12] DME. Energy Efficiency Accord. Pretoria: Department of Minerals and Energy; 2005.

[13] DTI. The 2010/11 - 2012/13 Industrial Policy Action Plan (IPAP II). Pretoria: Department of Trade and Industry; 2010.

[14] DEA. National Climate Change Response Green Paper 2010. Pretoria: Department of Environmental Affairs; 2010.

[15] DME. Draft Integrated Resources Plan for Electricity for South Africa 2010-2030. Pretoria: Department of Minerals and Energy; 2010.

[16] DEAT. Long Term Mitigation Scenarios Strategic Options for South Africa. Pretoria: Government Printer.; 2007.

[17] The Presidency. President Jacob Zuma to attend High Level Segment of the COP-15 scheduled for 18 December 2009 in Copenhagen. http://www.thepresidency.gov.za/show.asp?include=president/pr/2009/pr12 081345.htm\&ID=1933\&type=pr (accessed 9 December 2009)

[18] NBI. Energy Efficiency Accord signatories 2010. Johannesburg: National Business Initiative; 2010.

[19] DoE. Project Design Document. Department of Energy 2010 http://www.energy.gov.za/files/esources/kyoto/kyoto_frame.html December 2010)

[20] UNFCCC. CDM registered projects by region. UNFCCC 2010: URL: http://cdm.unfccc.int/Statistics/Registration/RegisteredProjByRegionPieCh art.html (accessed 20 December 2010)

[21] DME, NBI. Assessment study of the Energy Efficiency Accord. Pretoria/Johannesburg: Department of Minerals and Energy and National Business Initiative; 2008. 